\title{
THE SOFTWARE APPLICATION FOR MATHEMATIC DESCRIPTION OF EXTRACTION Process Course
}

\author{
Charvatova, H.; Janacova, D.; \\ FiALKA, M. \& KOLOMAZNIK, K.
}

Abstract: Many technological operations are based on a process of undesirable components removing from the solid material to the liquid phase. For propose of an optimal course of these components extraction, the physico-chemical formulation of the process is necessary to know. In the paper we deal with making of the software application of the removed component concentration field in the solid phase calculation during the extraction process. The calculation is based on analytical solution of the mathematical model of extraction process. We visualized the formatted dependence of the removing component concentration in the solid phase on the operating time in $2 D$ and $3 D$ projection for both real and dimensionless variables. We tested the application functions by calculation of course of extraction process deliming. The obtained values we verified by laboratory experiments. The application will be used for description of other extraction processes courses.

Key words: model, concentration field, extraction, software
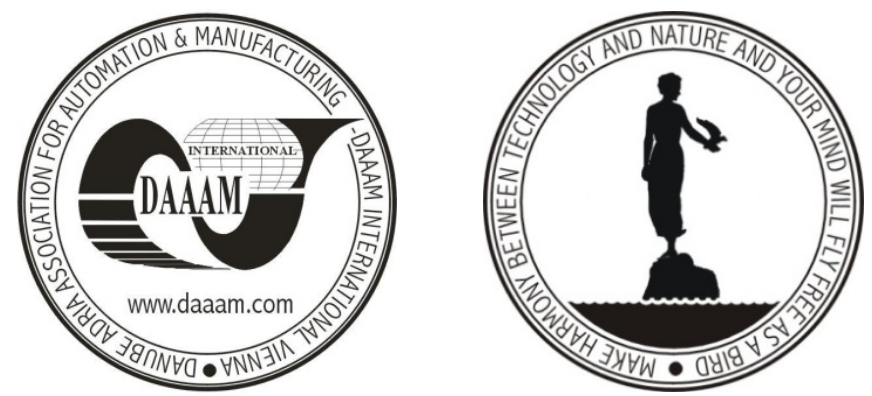

Authors' data: Ing., Ph.D. Charvatova, H[ana]; doc., Ing., CSc. Janacova, D[agmar]; RNDr., CSc. Fialka, M[iloslav]; prof., Ing., DrSc. Kolomaznik, K[arel], Tomas Bata University in Zlin, Faculty of Applied informatics, Nad Stranemi 4511, 760 05, Zlin, Czech Republic, charvatova@fai.utb.cz, janacova@fai.utb.cz, fialka@fai.utb.cz,kolomaznik@fai.utb.cz

This Publication has to be referred as: Charvatova, H[ana]; Janacova, D[agmar]; Fialka, M[iloslav] \& Kolomaznik, K[arel] (2009). The Software Application for Mathematic Description of Extraction Process Course, Chapter 02 in DAAAM International Scientific Book 2009, pp. 009-016, B. Katalinic (Ed.), Published by DAAAM International, ISBN 978-3-901509-69-8, ISSN 1726-9687, Vienna, Austria DOI: $10.2507 /$ daaam.scibook.2009.02 